\title{
The Royal Society and the origins of British archaeology: I
}

\author{
M. C. W. HUNTER
}

Mr Michael Hunter is a third-year undergraduate at fesus College, Cambridge. This is the first part of his article on the rôle of the Royal Society in the origins and development of archaeology in Britain.* The second part will be published in the next number of ANTIQUITY.

'The beginning of the modern world': Lytton Strachey's opinion of the foundation of the Royal Society, the opening remark to his essay on John Aubrey (Strachey, 1931, 19), retains an element of truth. For although the origins of modern science (and thus of the modern world) go back further than Strachey suspected, the Royal Society, with its aim of 'improving natural knowledge by experiments' zealously applied over many years, did much to lay the foundations of the empirical method of modern science, and gives English intellectual life of the late $17^{\text {th }}$ century a crucial role in the transition to the modern world (see Butterfield, 1957; Purver, 1967). Strachey went on to contrast the 'great age' of the Royal Society with the 'curious twilight period' of Hobbes and Aubrey which preceded it; he sensed a vital change in men's outlook in the I660's, and yet he discerned the essential continuity underlying it, a continuity symbolized in Aubrey.

The antiquarian thought of the late 17 th century reflects this general dichotomy. It inherited earlier traditions, but it was certainly modified by the Royal Society-as more than one writer has pointed out in recent years (Piggott, 1950, I-17 passim; Evans, 1956, 29; Piggott, 1956, 112 and passim; Fussner, 1962, 105; Piggott, 1965, 169). The extent of this influence is a problem: the archaeological

* The author is indebted to Professor R. J. C. Atkinson for his kindness in lending photostats of Books I-III of Aubrey's Monumenta Britannica, and to his friends, especially Sheridan Gilley, for their sympathetic criticism of this article. interests of men directly connected with the Royal Society undoubtedly differed greatly from those of Camden and his earlier followers, and it is true that the Society's activities were 'far closer to modern fieldwork' (Evans, I956, 29). But before this growing resemblance to the modern discipline of archaeology is attributed to the Society's scientific outlook, the antiquarianism of the period must be evaluated more carefully, defining the study of archaeology and tracing its earliest manifestations.

'Archaeology' is a relatively specialized historical science: 'if we use the phrase "historical research" to denote the discipline of obtaining knowledge of the human past from written records, we can recognize in "archaeology" a complementary group of techniques which utilizes material remains for the same ends', as Professor Piggott has put it (Piggott, 1956, 94). And whereas 'written records' range from historical narrative to inscriptions or even coins, material remains include such uninscribed and 'unconscious' relics of the past as potsherds, earthworks or even buildings, which impose upon the archaeologist lines of enquiry quite different from the historian's. For only if they are studied extensively and compared with similar objects, either modern or ancient, can material remains yield proper information about the culture, technology and economy of their period. It is this that concerns modern archaeology; mere collation of antiquities with historical sources is almost useless.

Translated into historical terms, this difference reflects the gulf between the antiquarian 


\section{ANTIQUITY}

research of Camden and his school and that of the Royal Society. Camden's Britannia and his contemporaries' and followers' books on allied subjects, though antiquarian in a broad sense, are certainly not archaeological in these narrow terms. Camden's consciousness was primarily historical, and his materials were almost all literary. Though they included written sources from archaeological contexts, such as inscriptions and coins, he had little interest in purely archaeological evidence, which appears in his narrative as an afterthought to his account of the history of a site, as with Folkestone, 'a flourishing place in times past, as may appeare by the peeces of Romane coine and Britaine brickes daily there found' (Camden, I6ro, 349). In general, his followers inherited his attitude. Thus Lee writes of Roman remains at Chester that 'the Romans residence in great numbers and plenty, their arched Vaults, and sweating houses, their Urns, coins, tesselated Pavements, do abundantly witnesse' (King, I656, II, 6), and similar finds were treated in an equally perfunctory way in Burton's Description of Leicestershire (1622). Such descriptions show no conception of the value of archaeological evidence as an autonomous province of historical enquiry.

This is made particularly clear by a tendency to quote earlier reports of finds rather than to add new ones, as in Harrison's Description of England (I577), in Burton's Commentary on Antoninus his Itinerary . . . so far as it concerneth Britain (1658), and in Philipot's Villare Cantianum (I659); in Lambarde's Perambulation of Kent ( 1576 ) and Erdeswicke's Survey of Staffordshire the sections on antiquities are more cursory still. John Norden, who lacked Camden's obsession with historical information, collected miscellaneous geographical and topographical matter for his County Surveys, to which archaeological evidence was only incidental, and in this he looks back to the less discriminating Leland rather than forward to modern archaeology. Even John Weever, who copied inscriptions in situ rather than secondary historical sources for his Ancient Funerall Monuments (I63I), seldom recorded archaeological finds and had little appreciation of their intrinsic value. Archaeology in the modern sense did not exist for these men.

The contrast is immediate and striking with the Royal Society's archaeological work in the I680's. The new tone appears in an article in the Philosophical Collections (Lister, 1682) about Roman antiquities from York, by Martin Lister, a York doctor who often contributed to the journal (see Stearns, 1967). Except for a single inscription quoted as a postscript, Lister examines only archaeological material and interprets it in purely archaeological terms. $\mathrm{He}$ divides Roman pottery from York into three types, one of them clearly Samian Ware, which he discusses in some detail, and the other two of different sorts of sandy clay. These clays Lister examined more carefully, thereby discovering the sites of the kilns where the pots were made, one near York and the other in Lincolnshire; he briefly describes the kilns, whilst his further comments on the pots, their lack of glazing and their black surface (the result of the reduction rather than oxidisation of the clay), also illustrate his purely technological concern. So does his denial of Camden's claim that certain Roman antiquities in Yorkshire were made of artificial stone (Camden, I6ro, 701 ), for Lister shows that they are in fact of millstone grit, whose source he traces, as he elsewhere tracks down the jet used for Roman ornaments in the York district. His singleminded concern with materials and their sources indicates the change coming over antiquarian studies.

A succession of archaeological articles in the Philosophical Transactions of the Royal Society for the following years shows the same interest in antiquities and their interpretation in their own terms. Lister published two further articles on antiquities from York, one of them identifying the multangular tower as Roman for the first time (Phil. Trans., XIII, 70-4, 237-42). Machell, the Westmorland antiquary, submitted a careful account of his examination of a Roman well at Kirkby Thore (Phil. Trans., xIII, 555-8); and, during the next two decades and beyond, there is an impressive series of articles on antiquities from the North of England by Ralph Thoresby, the Leeds antiquary (Phil. Trans., XIX, 319-20, 


\section{THE ROYAL SOCIETY AND BRITISH ARCHAEOLOGY}

663-4; Xx, 205-8, 310-2; XXII, II 56-8, I285-9; XXIII, 1864-5, 2I 45-8, 2149-5I, 2194-6; XXVI, I34-7, 289-91, 393-4), and Christopher Hunter of Durham (Phil. Trans., xxII, 657-8, I129-30; Xxx, 70I-4; XLV, I59-60; see Rogan, I954), whose exact records of Roman finds in this area were later to prove so valuable to John Horsley in the compilation of his Britannia Romana (1732). The Transactions also published some of Edward Lhwyd's detailed letters on his archaeological field-work in Ireland and Scotland (Phil. Trans., xxviI, 5०3-6, 524-6; XxvIII, 93-10r)*, whilst other archaeological contributions dealt with subjects ranging from Anglo-Saxon monuments (Phil. Trans, xIv, 1287-95) to Bronze Age metal-hoards (Phil. Trans., XXvI, 393-412), and for nearly a century important archaeological finds from all over the country were published in the Transactions. $\dagger$

A rich field for archaeological research was the City of London, being rebuilt at this time after the Great Fire. Sir Christopher Wren kept valuable notes of finds from building sites which were eventually published in his Parentalia (1750), whilst another antiquary of the Royal Society, John Conyers, 'made it his chief business to make curious observations, and to collect such Antiquities as were daily found in and about London' (Bagford, 1715, lxiii). Conyers recorded many finds, most of them unfortunately now known only at second hand, through Aubrey's Monumenta Britannica or Bagford's 'Letter relating to the Antiquities of London'; but one remarkable piece of work has survived, an account of Roman pottery kilns discovered whilst digging foundations for the new St Paul's Cathedral, with notes on other Roman finds from the City (Conyers, 105-9). Conyers describes in detail the kilns and the pottery found with them, illustrating his account with fine plans of the kilns and drawings of the pots. His interest in archaeology was scientific: the decomposition of metal and

* Dr Daniel has recently done justice to Lhwyd's archaeological work (Daniel, I967), and so I have largely omitted it from this article.

$\dagger$ Articles about British antiquities continue until the late 18 th century, their regularity varying not because of editorial policy (except before r680), but because the keenness of archaeological members of the organic materials from Roman sites in London preoccupied him in this account and elsewhere, whilst his other archaeological notes are interspersed amongst observations of natural scientific phenomena in the city and experiments on meteorological and other subjects. Conyers was particularly interested in stratigraphy, clearly stating its procedure in his account, suggesting that the relative depths of objects in the ground 'poynt and show' the different periods in which they were buried and so drawing conclusions about Roman and medieval finds (Conyers, Iogr). This use of the context of archaeological finds to gauge their significance is another aspect of the new archaeology.

John Aubrey was also at work in the I680's on his Monumenta Britannica (Aubrey, 24-5), which in its conception shows the change in interest: here, for the first time ever, was a great collection of purely archaeological material, without the miscellaneous information of Aubrey's own Natural History and Antiquities of Surrey (1718-19) and other topographical or historical surveys merely illustrated with isolated references to anquities. Books II and III, in particular, are full of information about archaeological remains which Aubrey gathered from his own observations and his friends' and classified by type: Urns and Barrows, Roman finds of different types, Camps and Castles, other types of earthwork, and miscellaneous items such as 'Hornes'-each was recorded in its own special section. There are limitations to these books: within the basic sub-divisions (themselves perhaps oddly ordered) Aubrey is muddled and often inconsistent. But his conception was sound and the Monumenta is an impressive collection of archaeological material.

Book IV, and to a lesser extent Book I, are more remarkable still, for here Aubrey uses the antiquities as a framework for evaluating individual specimens. Best of all is the 'Chronologia Architectonica', which Mr H. M. Colvin

Society fluctuated. Thus ten such articles appeared in the volumes for the I680's, eleven in the I690's, seventeen in the I700's, fourteen in the I710's, two in the 1720 's, none in the 1730's, twenty in the $1740^{\circ}$ 's, eight in the 1750 's and two in the 1760 's. Articles on foreign antiquities continue throughout this period and beyond it. 


\section{ANTIQUITY}

has recently highly praised (Colvin, I968): with great perspicacity, Aubrey collected a series of dated medieval buildings, noting the shape and tracery of their windows and other details, in order to build up a sequence of styles in English Gothic. He applied the same technique to palaeography, working, as he points out (Aubrey, 25, 185), in parallel with the great Mabillon, whose De Re Diplomatica appeared in $168 \mathrm{r}$. As early as 1672 Aubrey noted the evolution of handwriting from the Middle Ages to his own time, methodically applying to these relics of the past the concept of cultural and technological change that is basic to the discipline of archaeology. The same principle is also apparent in Aubrey's more haphazard 'Chronologias' of Clothing and of Scutcheons, and is implicit in more general terms in his notes on the diversity of weights and measures and on the rise of prices. Book $I$ is notable for his approach to the problem of megaliths from the study of the monuments themselves rather than from historical preconceptions, and his painstaking collection of details of megalithic remains from areas with no common culture in the historical period showed him that they were pre-Roman. It is no coincidence that in this he was nearer the truth than any of his historical predecessors. Here again there is a gulf between the writers of the school of Camden and the archaeologists of the Royal Society.

The Society also advanced technique, for it is to its archaeologists that we owe the beginnings of the modern excavation report, in the sense that deliberate excavation was described in a detailed published record. In the Philosophical Transactions for 1706 John Lyster reported on the excavation of a Roman hypocaust at Wroxeter (Lyster, 1706), whilst in 1717 Dr John Tabor of Lewes gave a similar account of a Roman bath and mosaic uncovered at Eastbourne (Tabor, 1717), and both measured the foundations revealed, describing the structure and the materials and methods of the builders in detail. Lyster's article contains the modern proviso that 'the form of the whole will be understood better by inspecting the Figures' (Lyster, I706, 2227) and both his and Tabor's accounts are accompanied by illustrations drawn to scale. In Lyster's article there is a plan, probably the first published archaeological plan with any pretensions to accuracy: Inigo Jones's diagram of Stonehenge in his StoneHeng Restored ( 1655 ) preceded it, but is too grossly stylized to be significant. This new care in recording antiquities was as characteristic of the Royal Society's archaeology as its fresh concern with unspectacular subjectmatter.

All this is so different from earlier antiquarianism that its origin is of considerable interest. That the Royal Society archaeologists were themselves conscious innovators is implied by their rejection of the Camdenian tradition dominant in antiquarian studies for a century. Thus in his Natural History of Staffordshire (1686), Dr Robert Plot wrote that 'I intend not to meddle with the pedigrees or descents either of families or lands . . .; nor of the antiquities or foundations of Religious houses, or any other pious or Civil performances: it being indeed my designe in this Chapter, to omit, as much as may be, both persons and actions, and chiefly apply my self to things; and amongst these too, only of such as are very remote from the present Age . . .; such as ancient Medalls, Ways, Lows, Pavements, Urns, Monuments of Stone, Fortifications, \&c., whether of the ancient Britans, Romans, Saxons, Danes, or Normans. Which being all made and fashioned out of Natural things, may as well be brought under a Natural History as any thing of $A r t^{\prime}$ (Plot, 1686, 392). In short, he insists on the study of archaeological evidence in isolation from the historical sources which were the domain of antiquaries like Camden. Archaeology and history were again distinguished in 1717 , when an article was omitted from the Philosophical Transactions because 'being chiefly Historical, it seems not so properly the subject of these Transactions' (Phil. Trans., xxx, 563). Lister echoed this in claiming to treat Roman relics from York 'only in the relation they may have to the advancement of Natural Philosophy and Arts' (Lister, I682, 87), thereby translating into archaeological terms the Society's characteristically careful study of man and nature, a process clearly illustrated by John Conyer's work. 


\section{THE ROYAL SOCIETY AND BRITISH ARCHAEOLOGY}

They were also attacked as innovators. John Batteley identified antiquaries and natural scientists in assailing both together in the final sections of his Antiquitates Rutupinae (I7II) (which nevertheless owes a great deal to the Royal Society). He deplored the useless pursuit of unimportant phenomena for their own sake as a waste of time, for 'propter ea antiquitatis studium e republica literaria exturbari' (Batteley, I7II, 90). 'Scilicet facilius est', Batteley says, 'res in oculos nostros sive perspicillorum, ut vocant, ope, sivi simplici obtutu incurrentes, notare, atque discribere, quam de antiquitatis monumentis recte judicare.' And by correct judgement Batteley meant the wholesale, and inappropriate, correlation of ordinary finds from Kentish sites with statements of classical and later authors.

This passage shows that the opponents of the Royal Society, and by implication its predecessors, found an interest in antiquities for themselves inconceivable. It also suggests that this was a new interest, inspired by the Society's concern with 'unimportant' phenomena in other fields, which contemporaries found equally strange, not understanding those who 'studi'd these twenty years to find out the several sorts of Spiders, and never [cared] for understanding Mankind' (Shadwell, 1676 , ro). If they were correct, the new scientists created the new archaeology, and the pioneers of the one pioneered the other.

Antiquarian work of the mid-I 7 th century suggests that they were at least partly right, for there are few signs there of modern archaeology. William Dugdale devoted five columns to barrows in his Antiquities of Warwickshire $\left({ }^{6} 6_{5} 6\right)$, but his sources were mostly literary, and his observation and evaluation of individual antiquities only incidental to them (Dugdale, I656, 3-5). Equally disappointing are four monographs inspired by a controversy in the I650's and 6o's about Stonehenge, a monument too impressive to escape the attentions of antiquaries usually uninterested in such remains, from Geoffrey of Monmouth to Camden. The approach to the problem was set by Inigo Jones's Stone-Heng Restored (1655), which provoked Charleton's Chorea Gigantum (1663),
Webb's Vindication of Stone-Heng Restored (1665) and Gibbons's $A$ Fools Bolt soon Shott at Stonage. Although Jones described the monument in some detail in Stone-Heng Restored, his main interest was its historical context, the theme to which he devoted the bulk of the book, whilst he dismissed the prehistoric or Arthurian claims to the monument because of the bestial condition of the Britons before and after the Roman occupation, which he argued from purely literary evidence. Arguing also on literary grounds, and from parallels with megaliths in Denmark, Charleton denied Jones's interpretation and advanced his own theory of a 9th-century Danish origin. Webb's attack on Charleton is less interesting for reasserting Jones's original theory with more vehemence and less ingenuity than for its criticism of Charleton's Danish parallels and of their source, Olaf Worm, for this raises Professor Piggott's query as to the influence of continental scholarship on the English antiquaries in this period (Piggott, 1956, 107).

In a piecemeal form, the impact of Worm's Danicorum Monumentorum Libri Sex (I643) was undoubtedly great: it is often quoted at this time on megalithic remains and early Northern burial rites (King, I656, III, Io; Dugdale, $165_{6}^{6}$, 3; Browne, 1658 , 228; Charleton, $1663,37-5 \circ$, 57; Plot, 1677, 324, 338-9; Browne, 1684, I 53; Morton, I7I2, 53I), whilst its study of runes inspired Aubrey to similar investigations and it is the principal source of Aubrey's essay on drinking horns in the Monumenta. In method, however, Worm's importance is small. Only a sixth of his book is devoted to uninscribed antiquities of the sort which concern us here, and this is by no means the best part of the whole, which is chiefly important for its epigraphic study of runes. Dividing the megaliths of Denmark into classes, Worm arbitrarily correlates stone-circles with several historical theories which he should have weighed up critically; one feels that he is as much an historian as Camden, but that with more antiquities like Stonehenge and fewer authorities to explain them, he has to make his material go further. Of the study of antiquities in their own terms there is hardly a glimpse here, and 


\section{ANTIQUITY}

his viewpoint was invariably literary. Only in Aubrey and Lhwyd does the change of priorities bring men within sight of the true date of the megaliths.

So the new archaeology did not come from Scandinavia, for Worm and his English disciples only show more clearly the Royal Society's novelty. The real source of the new attitude towards antiquities must be sought elsewhere, in a more careful examination of the Society's predecessors, and in earlier and rarer instances of their kind of antiquarian work. For, even applying the same narrow definition of archaeology in the modern sense, our search takes us back to the Middle Ages and to a $15^{\text {th }}$ century chronicler who applied to material remains of the past that concept of cultural and technological change which seems so remarkable in Aubrey.*

In his Warwick Rolls, John Rous (14II-9I) executed drawings of past Earls of Warwick and he deliberately dressed his characters in the armour of the period in which they lived--with Saxon earls in long mail hauberks, $14^{\text {th-century }}$ knights in mixed mail and plate armour, and full-plate armour for his most recent figures. Whether or not it is true, as Sir James Mann suggested (Mann, 1933, 262), that the early armour of the Earls must have been preserved in Warwick Castle in Rous's time, this attempt to trace the development of armour was of remarkable precocity: though less explicit than the similar work in Book IV of Aubrey's Monumenta, it can hardly have been less deliberate. Rous's contemporary, William Worcestre, was also a precursor of archaeology in the modern sense, as his recent editor has pointed out (Harvey, $1969, x i-x i i)$. Worcestre measured a great many ecclesiastical buildings and listed castles, purely for the sake of doing so-thus anticipating the

\footnotetext{
* Instances of medieval antiquarianism before Rous include Matthew Paris's detailed catalogue of the gems in the Treasury of St Albans (Chronica Maiora, ed. H. R. Luard, VI (London: Longmans, I882), frontispiece) and Thomas of Elmham's similar description appended to his careful drawing of a seal in the chartulary of St Augustine's, Canterbury (Trinity Hall, Cambridge, MS I, 24r). For William Worcestre's precursors see Harvey, 1969 , xii. See also Wright, I844, 1849; Mann, I933.
}

Royal Society's archaeologists' unprejudiced observation of antiquities, although neither he nor Rous was concerned with the specifically archaeological material that won the attention of their successors.

A wider interest in antiquarian studies of every sort grew in the 16th century. Leland was a pioneer in recording Roman inscriptions and other finds, whilst systematic epigraphy began with the 1607 edition of Camden's Britannia, and the first monograph on archaeological remains may date from the Elizabethan period, although at present none has survived from earlier than the Civil War. Spitalfields in London was 'described, and likewise observed to have been a Roman Camp by a judicious Author in the latter end of Queen Elizabeth's Reign, published in a valuable Quarto pamphlet' (Bagford, 1715, 1xi-ii), but unfortunately our authority for this had 'forgot the Author's name'. Spitalfields, however, was also the subject of a detailed archaeological account, like those published a century later in the Philosophical Transactions, which appeared in a larger book, Stow's Survey of London (1598). Discussing a Roman cemetery found there in I 576, * Stow described the pottery unearthed at length, noting its consistency and shape like Lister in his article, whilst more remarkable still was Stow's approach to an archaeological problem that arose at the site: many large nails were found, thought by onlookers to have been used to smash the skulls of the corpses, but Stow, sensibly doubting this, believed them to be part of the coffins used in the burials. Noting the distribution of the nails around one of the bodies--'round about him, as thwart his head along both his sides, \& thwart his feete' (Stow, 1 598, 132)-he asked a man digging on the site to pass him some of the nails, and proved his point by showing that they still had traces of wood under their heads. Here, in 1576 , is the careful study of antiquities, free from historical or literary preconceptions, just like the work of the Royal Society a century later.

Such investigations are not common, but they give warning against rash claims about

*Perhaps the same finds were described in the lost quarto pamphlet. 


\section{THE ROYAL SOCIETY AND BRITISH ARCHAEOLOGY}

'beginnings'. Another account occurs in the unlikely context of Meric Casaubon's Notes to his translation of the Meditations of Marcus Aurelius (1634), where again, as in Stow, the description is no mere illustration to an historical narrative. In a long passage of the Notes, Casaubon discusses a Roman burial ground near Newington in Kent, describing in detail the pottery found and its grouping (Casaubon, $1634,3^{1-6}$ ). In considering the finds, Casaubon quates from Jan Gruter (1560-1627), whose monumental Inscriptiones antiquae totius orbis Romani had appeared in 1603 , a clear case of continental influence, for Casaubon makes it clear that however 'common' his countrymen might consider such a find, 'by the learned Antiquaries beyond the Seas... [it] would bee much esteemed' (Casaubon, 1634, 31). Casaubon's summary of the conclusions suggested by the finds is both sensible and valuable, but perhaps the most remarkable feature of his account of the Newington cemetery was an engraved plate that illustrates some of the pottery - an urn with a roughly executed inscription, a flagon, an indented Castor urn, and a cup and dish (stamped 'Coccillim') of Samian ware. This precedes by nearly a quarter of a century Sir Thomas Browne's Hydriotaphia, which has been claimed as the earliest book illustrating pottery in this country. And since that claim accompanied the statement that it was 'perhaps not by chance' that the pots 'were thought worthy of visual record by a doctor of medicine' (Piggott, 1965, 169), it is worth pointing out that Meric Casaubon was firmly rooted in his father's sober traditions of Renaissance classical scholarship, and the father at least was utterly remote from the new scientific impulses of the $17^{\text {th }}$ century (cf. Pattison, 1875).

These examples disprove any claim that the men associated with the Royal Society in the late $17^{\text {th }}$ century were the first to see the intrinsic interest of antiquities; they only continued and enlarged upon precedent. What is more, all these earlier writers were wholly medieval or Renaissance figures. However modern parts of Rous's work may seem to us, he was in his ideas and aspirations 'a traditional medieval antiquary' (Kendrick, 1950, 22); Stow shared the historical outlook of Camden (Levy, 1967, 163); Casaubon stood close to a pure classical Renaissance humanism. None of these men herald the Royal Society, and yet, as we have seen, their work closely resembled its antiquarian activities. The association of modern science and the beginnings of archaeology thus seems dubious.

What of the technical advances which have been attributed to the close association of archaeology with science in the Royal Society? Dr Daniel has drawn attention to Edward Lhwyd's use of stratigraphy at New Grange (Daniel, 1967, 353-5), and an equally striking application of the same technique occurs in John Woodward's 'An Account of some Roman Urns and other Antiquities lately Digg'd up near Bishops-gate', in which a coin associated with a Roman burial found at Camomile Street was employed to date the Roman walls of London (Woodward, 1712,25 ). It is no doubt significant that Woodward and Lhwyd were both palaeontologists, and that for both stratigraphy was central to their argument. But they were not without precursors: Camden noted that 'Hellens money [is] oftentimes found under the Walles' to illustrate his historical proof of the age of London's walls (Camden, I6ro, 423), and the less sophisticated but closely allied technique of association was also employed for dating in Camden's period (Camden, I6ro, passim; Sir Robert Cotton, quoted in Weever, 1631, 30; Weever, 163r, 6r8). Just as Aubrey's 'scientific' method of classification for constructing a typological framework in his 'Chronologias' has a precedent in the $15^{\text {th }}$ century, so this should be a warning against claims that such techniques are of scientific origin.

Indeed, science merely made the uncommon commonplace. It is less important that Lhwyd and Woodward were scientists than that the use of stratigraphy became customary amongst the Royal Society's archaeologists, including Conyers (who was not a palaeontologist)*. So with other aids to the study of antiquities;

* On Conyers's stratigraphy, see above, p. I 15. The use of association and a rudimentary understanding of stratigraphy appear in Aubrey's discussion of the 


\section{ANTIQUITY}

Camden had observed cropmarks at Richborough and at Wroxeter (Camden, 16ro, 342, 593), but these were isolated cases and only with the Royal Society did the practice become usual-John Wilkins and Seth Ward noted them when they visited Silchester in $x 65^{8}$ (Aubrey, $24,2 \times 5)$, like other Royal Society archaeologists later (Morton, I712, 511 ; Tabor, 1717, 550). And if we owe the modern excavation report to archaeologists associated with the Royal Society, this only consolidated a more haphazard tradition of deliberate excavation, mainly of barrows, going back to the Middle Ages (e.g., Wright, I844, I849; Twyne, I590, 75; King, 1656, III, I0; Oglander, I888, I I8). Antiquities could be empirically approached before the Royal Society as after it; only the general imprecision of surviving accounts of these investigations contrasts with the detail of later reports to illustrate the change wrought by the Royal Society in this field as in others.

This is the importance of the Royal Society to archaeology. Neither in interests nor in techniques did it innovate-but its new emphasis focused and intensified both. Antiquarian preoccupations of the late 16 th and early $17^{\text {th }}$ centuries always remained historical and

Devil's Ditch (Aubrey, 25, 88); Long's letter to Aubrey transcribed in Aubrey, 25, 130; Batteley, 1711,89 (though his application of it is limited); Browne, 1712, 7; and Morton, 1712, 509, 521, etc. Aubrey's interest in intersecting Roman roads (Aubrey, 25, 96, 99) suggests that he hoped that by studying the places where they joined he would be able to judge their relative dates. linguistic, and excursions into archaeology proper were merely incidental. At the end of the $17^{\text {th }}$ century, this hitherto minor concern was developed, and the Royal Society is responsible for the resulting refashioning of antiquarianism. For by providing a new intellectual climate where minute and ostensibly pointless studies were respectable, the Royal Society made possible the study of 'things' to the exclusion of 'persons and actions'--a dichotomy of great importance, for it has left its mark in the modern distinction between history and archaeology. Moreover, the Society's influence as an institution propagated the new principle and applied it in practice, sponsoring much work by publishing it in its Philosophical Transactions, and encouraging and approving more as independent research. By providing a forum for the exchange of views on all subjects the Society interested a growing number of people in archaeological studies of a modern type, and these made up the large circle of wellinformed correspondents who investigated archaeological sites and gave Aubrey material for his Monumenta. From the 1680's onwards it developed archaeological research to a degree hitherto unknown, contributing a new refinement in recording and interpreting finds, producing a great body of work in a short space of time, and consolidating it into a monograph of a new kind, Aubrey's Monumenta Britannica. This sudden flowering is inseparably linked to the Society's influence, and, if the origins of archaeology are remote, the Royal Society first defined it.

\section{BIBLIOGRAPHY}

AUBrey, JoHN. Monumenta Britannica, Vol. I (Bodleian Library, Oxford, MS Top. Gen. c. 24); Vol. II (Bodleian MS Top. Gen. c. 25).

BAGFORD, JOHN. 1715. Letter relating to the Antiquities of London, in J. Leland, Collecteana ed. T. Hearne, Vol. I (Oxford: at the Theatre), Iviii-lxxxvi,

BATTELEY, JOHN. I7II. Antiquitates Rutupinae (Oxford: at the Sheldonian).

BROWNE, SIR THOMAS. 1658. Hydriotaphia, UrneBuriall, or, A Discourse of the Sepulchral Urnes lately found in Norfolk (London: Brome). 1684. Of Artificial Hills, Mounts or Burrows, In many parts of England, in Certain Miscellany Tracts (London: for Mearne), I 5 I-6.

1712. Concerning some Urnes found in BramptonField, in Norfolk, Ann. 1667, in Posthumous Works (London: Curll); paginated separately. BUTTERFIELD, HERBERT. 1957. The origins of modern science (Revised edition; London).

CAMDEN, WILLIAM. I610. Britain, or a Chorographical Description of the most flourishing Kingdomes, England, Scotland and Ireland, translated by P. Holland (London: Bishop).

Casaubon, Meric. 1634. M.Aurelius Antoninus his Meditations Concerning Fimself . . . Translated 


\section{THE ROYAL SOCIETY AND BRITISH ARCHAEOLOGY}

out of the Originall Greeke; with Notes by ... . Meric Casaubon (London: Flesher); notes paginated separately.

CHARLETON, WALTER. 1663. Chorea Gigantum (London: Herringman).

Colvin, н. M. 1968. Aubrey's Chronologia Architectonica, in (ed.) J. Summerson, Concerning architecture, essays presented to N. Pevsner, (London), I-I2.

CONYERS, JOHN. British Museum MS Sloane 958. The plans are reproduced in the Victoria County History of London, I (1909), 124.

DANIEL, G. E. I967. Edward Lhwyd: antiquary and archaeologist, Welsh History Review, III, 345-59.

DUgDale, William. 1656. The Antiquities of Warvickshire (London: Warren).

EVANS, JOAN. 1956. A history of the Society of Antiquaries (Oxford).

FUSSNER, F. S. I962. The historical revolution (London). HARVEY, JOHN (ed.). I969. W. Worcestre, Itineraries (Oxford).

KENDRICK, T. D. I950. British antiquity (London).

KING, DANIEL. 1656. The Vale Royal of England (London: Streater). Part It of this work is by S. Lee, and Part III by J. Chaloner.

LEVY, F. J. 1967. Tudor historical thought (San Marino: Huntington Library).

LISTER, MARTIN. 1682. A Letter from Dr Lister of York, containing an account of several curious observations made by him about Antiquities, \&c, Philosophical Collections, Iv, 87-92.

LYNCH, B. D. and T. F. 1968 . The beginnings of a scientific approach to prehistoric archaeology in $17^{\text {th }}$ and 18 th century Britain, South West Fournal of Anthropology, xxiv, 33-65.

LYSTER, JOHN. 1706. A Description of a Roman Sudatory, or Hypocaustum, found at Wroxeter in Shropshire, Philosophical Transactions, xxIII, 2226-7, with interpretations by other writers, 2228-33.

MANN, SIR JAMES. T933. Instances of antiquarian feeling in medieval and renaissance art, Arch. F., LXXXIX, 254-74.

MORTON, JOHN. 1712. Natural History of Northamptonshire (London: Knaplock \& Wilkins).

OGLANDER, SIR JOHN. I888. Oglander Memoirs, ed. W. H. Long (London: Reeves \& Turner).

PATTISON, MARK. 1875. Isaac Casaubon, I559-16r4 (London: Longmans).
PHILOSOPHICAL TRANSACTIONS of the Royal Society of London (from 1665).

PIGGOTT, STUART. 1950. William Stukeley: an eighteenth-century antiquary (Oxford).

1956. Antiquarian thought in the sixteenth and seventeenth centuries, in (ed.) L. Fox, English historical scholarship in the sixteenth and seventeenth centuries (Oxford), 93-I I4.

1965. Archaeological draughtsmanship: principles and practice. Part I: principles and retrospect, Antiquity, $\mathrm{xxxIx}, 165-76$.

PLOT, ROBERT. 1677. Natural History of Oxfordshire (Oxford: at the Theatre).

1686. Natural History of Staffordshire (Oxford: at the Theatre).

PURver, M. 1967. The Royal Society: concept and Creation (London).

ROGAN, JOHN. 1954. Christopher Hunter, antiquary, Archaeologia Aeliana, 4th series, XxxIr, I16-25.

SHADWELL, THOMAS, 1676. The Virtuoso (London: Herringman).

stearns, R. P. (ed.) 1967. M. Lister, $A$ Yourney to Paris in the year 1698 (Urbana: University of Illinois Press).

stow, JoHN. ז598. Survey of London (London: Wolfe).

STRACHEY, LYTTON. 1931. John Aubrey, in Portraits in miniature (London), 19-28.

TABOR, JOHN. I7I7. An accurate Account of a tessellated Pavement, Bath, and other Roman Antiquities, lately discover'd near East Bourne, Philosophical Transactions, xxx, 549-63, 783-802.

TWYNe, John. 1590. De Rebus Albionicis atque Anglicis (London: Watkins).

WeEver, JoHn. I631. Ancient Funerall Monuments (London: Harper).

WOODWARD, JOHN. I7I2. An Account of some Roman Urns, and other Antiquities, lately Digg'd up near Bishops-gate... In a letter to Sir Christopher Wren...., appended to J. Leland, Itinerary, ed. T. Hearne, Vol. viII (Oxford: at the Theatre).

WRIGHT, THOMAS. I 844. On Antiquarian Excavation and Researches in the Middle Ages, Archaeologia, $\mathrm{xxx}, 43^{8-57}$.

1849. On some early Notices relating to the Antiquities of St Albans, Archaeologia, xxxıII, $262-8$. 